\title{
Intrageneric Structure of the Genus Rhodobacter: Transfer of Rhodobacter sulfidophilus and Related Marine Species to the Genus Rhodovulum gen. nov.
}

\author{
A. HIRAISHI* AND Y. UEDA \\ Laboratory of Environmental Biotechnology, Konishi Co., \\ Yokokawa 5-6-3, Sumida-ku, Tokyo 130, Japan
}

\begin{abstract}
Phylogenetic relationships among species of the genus Rhodobacter and related taxa were elucidated by studying 16S rRNA sequence information and genomic DNA homology data. The 16S rRNA gene was amplified by the PCR and was sequenced directly by a combined method consisting of cycle sequencing and automated fluorescence detection. Pairwise sequence comparisons and a distance matrix analysis showed that the Rhodobacter species could be divided into two major clusters; one cluster included the freshwater and terrestrial species, and the other cluster contained the marine species. The cluster containing the freshwater Rhodobacter species also included Rhodopseudomonas blastica and was linked more closely to the chemotroph Paracoccus denitrificans and the aerobic phototroph Roseobacter denitrificans than to the cluster containing the marine Rhodobacter species. Genomic DNA-DNA hybridization data supported the results of 16S ribosomal DNA sequence comparisons. With few exceptions, the marine Rhodobacter species can be differentiated phenotypically from the freshwater species on the basis of salt requirement for optimal growth, sulfide tolerance, final oxidation product of sulfide, and polar lipid composition. Thus, we propose that all marine Rhodobacter species should be transferred to the genus Rhodovulum gen. nov.; Rhodovulum sulfidophilum comb. nov. is the type species of this genus.
\end{abstract}

In 1984 Imhoff et al. (25) described a rearrangement of the genera and species of phototrophic purple nonsulfur bacteria and proposed creation of the new genus Rhodobacter and the new combinations Rhodobacter adriaticus, Rhodobacter capsulatus (type species), Rhodobacter sphaeroides, and Rhodobacter sulfidophilus, all of which had been included previously in the genus Rhodopseudomonas. Since then, two new species, Rhodobacter veldkampii (12) and Rhodobacter euryhalinus (31), have been added to this genus. Strains of Rhodobacter species are gram negative and facultatively photoheterotrophic and are characterized by their ovoid to rod-shaped morphology, their formation of vesicular intracytoplasmic membranes together with carotenoids of the spheroidene series, and their ability to grow anaerobically and phototrophically in the presence of sulfide as an electron donor (23). They are also similar in their chemotaxonomic properties, such as quinone compositions $(18,19$, $22)$, fatty acid profiles $(24,28)$, and lipid A structures (42, 43). Although Rhodobacter species share many common characteristics, as noted above, they can be divided clearly into two groups on the basis of their natural habitats. Freshwater and terrestrial environments are common sources of Rhodobacter capsulatus, Rhodobacter sphaeroides, and Rhodobacter veldkampii, while Rhodobacter adriaticus, Rhodobacter euryhalinus, and Rhodobacter sulfidophilus are found only in marine and hypersaline environments. As suggested by their natural habitats, strains of the latter three species require 0.5 to $7.5 \% \mathrm{NaCl}$ for optimal growth. There are also differences in polar lipid composition (24) and some other phenotypic traits among Rhodobacter species.

\footnotetext{
* Corresponding author. Mailing address: Laboratory of Environmental Biotechnology, Konishi Co., Ltd., Yokokawa 5-6-3, Sumidaku, Tokyo 130, Japan. Phone: 81-03-3625-5714. Fax: 81-03-36255660 .
}

The phylogenetic affiliations of members of the genus Rhodobacter, as well as other phototrophic bacteria and their nonphototrophic relatives, have been estimated on the basis of structures and amino acid sequences of cytochrome $c(1,5), 16 \mathrm{~S}$ rRNA oligonucleotide catalogs $(11,46,47)$ and sequences $(29,32,45)$, rRNA operon structures (6), and rRNA cistron similarities (4). An important conclusion deduced from these molecular approaches is that Rhodobacter species are more closely related to the chemotrophic bacterium Paracoccus denitrificans than to other members of the phototrophic bacteria belonging to the alpha group of the class Proteobacteria (39). It is also noteworthy that there is a close phylogenetic relationship between Rhodobacter species and a phototroph with lamellar membranes, Rhodopseudomonas blastica, as shown by the results of DNArRNA reassociation assays (4), immunological analyses of malate dehydrogenase (40), and 16S rRNA sequence comparisons (29). These findings have led some workers to propose that Rhodopseudomonas blastica should be transferred to the genus Rhodobacter $(4,29)$ and to suggest that the types of intracytoplasmic membrane systems are of questionable value as generic criteria (29). Moreover, DNArRNA pairing studies have shown that there are closer affinities among some freshwater Rhodobacter species, Rhodopseudomonas blastica, and Paracoccus denitrificans than between the freshwater Rhodobacter species and the marine species Rhodobacter sulfidophilus (4). Genomic DNA-DNA hybridization studies have provided some information about the intrageneric structure of and interspecies relationships within the genus Rhodobacter $(3,26)$. At present, the genus Rhodobacter is considered the taxonomically best characterized genus among genera belonging to the alpha subclass of phototrophic proteobacteria (23). However, circumstantial evidence suggests that there is still phylogenetic and phenotypic diversity among members of this genus.

The present study was undertaken to investigate more 
TABLE 1. Bacterial strains studied and accession numbers for their 16S rDNA sequences

\begin{tabular}{|c|c|c|c|c|}
\hline Species & $\begin{array}{l}\text { Strain designation or } \\
\text { received as strain }{ }^{a} \text { : }\end{array}$ & Other designation(s) or source ${ }^{a}$ & Reference & $\begin{array}{l}\text { Nucleotide sequence } \\
\text { accession no. }\end{array}$ \\
\hline \multicolumn{5}{|l|}{ Freshwater species } \\
\hline \multirow[t]{2}{*}{ Rhodobacter capsulatus } & ATCC $11166^{\mathrm{T} b}$ & DSM $1710^{\mathrm{T}}$, C. B. $\operatorname{van}$ Niel ATH $2.3 .1^{\mathrm{T}}$ & 36 & D16428 \\
\hline & $\mathrm{C} 5$ & $\begin{array}{l}\text { Collection of A.H., isolated from a paddy } \\
\text { field }\end{array}$ & & D16427 \\
\hline \multirow[t]{2}{*}{ Rhodobacter sphaeroides } & IFO $12203^{\mathrm{T}}$ & $\begin{array}{l}\text { ATCC } 17023^{\mathrm{T}} \text {, DSM } 158^{\mathrm{T}} \text {, C. B. van Niel } \\
\text { ATH } 2.4 .1^{\mathrm{T}}\end{array}$ & 36 & D16425 \\
\hline & IL106 & T. Satoh & 38 & D16424 \\
\hline Rhodobacter veldkampii & ATCC $35703^{\mathrm{T}}$ & T. A. Hansen $51^{T}$ & 12 & D16421 \\
\hline $\begin{array}{l}\text { Rhodopseudomonas } \\
\quad \text { blastica }\end{array}$ & ATCC $33485^{\mathrm{T}}$ & DSM $2131^{\mathrm{T}}, \mathrm{NCIB} 11576^{\mathrm{T}}$ & 7 & D16429 \\
\hline \multicolumn{5}{|l|}{ Marine species } \\
\hline Rhodobacter adriaticus & DSM $2781^{\mathbf{T}}$ & J. F. Imhoff $6 \mathrm{II}^{\mathbf{T}}$ & 35 & D16418 \\
\hline Rhodobacter euryhalinus & DSM $4868^{\mathrm{T}}$ & E. I. Kompantseva KA- $65^{\mathrm{T}}$ & 31 & D16426 \\
\hline \multirow[t]{3}{*}{ Rhodobacter sulfidophilus } & DSM $1374^{\text {T }}$ & T. A. Hansen W4 ${ }^{\mathrm{T}}$ & 14 & D16423 \\
\hline & DSM 2351 & T. A. Hansen W12 & 14 & D16430 \\
\hline & TW13 & Collection of A.H., isolated from a tide pool & 19 & D16422 \\
\hline Rhodobacter sp. & MB260 & Collection of A.H., isolated from a tide pool & & D16420 \\
\hline Rhodobacter sp. & MB-G2 & Collection of A.H., isolated from a tide pool & & D16419 \\
\hline
\end{tabular}

${ }^{a}$ ATCC, American Type Culture Collection, Rockville, Md.; IFO, Institute for Fermentation, Osaka, Japan; DSM, Deutsche Sammlung von Mikroorganismen, Göttingen, Germany; NCIB, National Collection of Industrial Bacteria, Aberdeen, United Kingdom; A.H., A. Hiraishi, Laboratory of Environmental Biotechnology, Konishi Co., Tokyo, Japan.

${ }^{b} \mathrm{~T}=$ type strain.

thoroughly the intrageneric structure of the genus Rhodobacter by means of direct automated sequencing of PCRamplified 16S rRNA genes and genomic DNA-DNA pairing. On the basis of the results of these molecular approaches and previous phenotypic information, we propose that Rhodobacter sulfidophilus and related marine species should be transferred to a new genus, Rhodovulum.

\section{MATERIALS AND METHODS}

Bacterial cultures and cultivation. The test bacteria included 10 strains belonging to six previously described species of the genus Rhodobacter, 2 strains belonging to unknown Rhodobacter species, and one strain of Rhodopseudomonas blastica (Table 1). Rhodobacter capsulatus C5 and the two strains belonging to the unknown Rhodobacter species, MB260 and MB-G2, were new strains isolated by one of us (A.H.) from the environment. MYS medium (18) and modifications of this medium were used to cultivate the organisms. The medium was modified by adding $2 \mathrm{mM}$ cysteine (filter sterilized) for the growth of Rhodobacter veldkampii. For most marine species, $0.5 \mathrm{mM}$ sodium thiosulfate, $0.5 \mathrm{mM}$ sodium sulfide, and $3 \% \mathrm{NaCl}$ were added to the medium; the concentration of $\mathrm{NaCl}$ was reduced to $1 \%$ for Rhodobacter euryhalinus and Rhodobacter sp. strain MB-G2. The organisms were grown anaerobically at $30^{\circ} \mathrm{C}$ in screw-cap test tubes or bottles filled with medium under incandescent illumination (ca. 5,000 lux). Cells were harvested by centrifugation from cultures at the mid-exponential phase of growth, washed with sterilized $1 \%$ saline, resuspended either in pure water (for PCR experiments) or in EDTA-saline (for DNA hybridization studies), and stored at $-20^{\circ} \mathrm{C}$ until they were used.

PCR amplification and sequencing of 16S rDNA. Crude lysates were prepared from stock cell suspensions by protease digestion, heat treatment, and centrifugation. 16S ribosomal DNA (rDNA) fragments were amplified by the PCR directly from the crude extract, using a commercial PCR kit, Taq DNA polymerase, and a pair of eubacterial consensus primers homologous or complementary to posi- tions 8 to 27 and 1492 to 1510 (44) (all positions indicated for the 16S rRNA molecule refer to the Escherichia coli numbering system [2]). Detailed information concerning the procedures used has been given elsewhere $(16,17)$. PCR products were extracted with chloroform-isoamyl alcohol (24:1 [vol/vol]), precipitated with ammonium acetate and ethanol, and purified by agarose gel electrophoresis. Separated fragments were cut from the gel and withdrawn with a Sepaglas BandPrep kit (Pharmacia LKB Biotechnology, Uppsala, Sweden) according to the manufacturer's instructions. PCR-amplified double-stranded 16S rDNA was sequenced directly by the linear PCR amplification (cycle sequencing) method $(8,34)$ with a Pharmacia AutoCycle sequencing kit and was analyzed with a Pharmacia A.L.F. laser fluorescent DNA sequencer as described previously $(16,17)$.

Phylogenetic analysis. Pairs of sequences were aligned, and similarities were calculated with the GENETYX computer program (Software Development Co., Tokyo, Japan). Nucleotide substitution rates $\left(K_{\text {nuc }}\right)(30)$ were determined, and a distance matrix tree was constructed by the neighborjoining method (37), using the CLUSTAL V program (15). Alignment gaps and unidentified base positions were not taken into consideration for the calculations. The topology of the phylogenetic tree was evaluated by performing a bootstrap analysis (10) with 1,000 bootstrapped trials.

DNA base composition and DNA-DNA homology. Genomic DNAs were extracted and purified by the method of Marmur (33). DNA base compositions ( $\mathrm{G}+\mathrm{C}$ contents) were determined by high-performance liquid chromatography (HPLC) of nuclease P1 hydrolysates of genomic DNAs, using external standards obtained from Yamasa Shoyu Co., Choshi, Japan (20). DNA-DNA paring studies were performed by the quantitative dot blot hybridization method with photobiotin labeling and colorimetric detection $(9,20)$.

Nucleotide sequence accession numbers. The $16 \mathrm{~S}$ rDNA sequences determined in this study have been deposited in the DDBJ, EMBL, and GenBank nucleotide sequence data bases under accession numbers D16418 to D16430 (Table 1). 
The accession numbers of the sequences used as references are follows: Erythrobacter longus, M59062; Escherichia coli, J01859; P. denitrificans, X69159; Rhodomicrobium vannielii, M34127; Rhodopila globiformis, M59066; Rhodopseudomonas acidophila, M34128; Rhodopseudomonas marina, M27534; Rhodopseudomonas palustris, M59068; Rhodospirillum molischianum, M59067; Rhodospirillum rubrum, M32020; Rhodospirillum salexigens, M59070; Roseobacter denitrificans (formerly Erythrobacter sp. strain OCh 114), M59063.

\section{RESULTS AND DISCUSSION}

The PCR-amplified 16S rDNA sequences of 12 strains of Rhodobacter species and one strain of Rhodopseudomonas blastica were determined by the combined method consisting of cycle sequencing and automated fluorescence detection. All of the fragments, except the PCR primer-annealing regions, made up a continuous nucleotide region stretching from position 28 to position 1491 (length, 1,386 to 1,390 residues). With few exceptions, the 16S rRNA structures of all of the test strains deduced from the rDNA sequence information included the definitive signatures of the alpha subdivision of the Proteobacteria (45), and the 16S rRNAs had nucleotide deletions in loop helices at positions 74 to 94 , 201 to 215,452 to 479 , and 1258 to 1278 . Also, as described previously for Rhodobacter sphaeroides 16S rRNA (6), the unusual large stem-loop around position 1,450 which contained one to four bases more than the stem-loop of $E$. coli was observed in all test organisms. Characteristic differences in 16S rRNA nucleotide signatures between the freshwater and marine Rhodobacter species were also found (see below).

From the sequence data obtained binary sequence similarity and evolutionary distance $\left(K_{\text {nuc }}\right)$ values were calculated for the 13 test strains and some reference organisms. To have as many alignable positions as possible for the calculations, we first attempted to add only two reference sequences, the reference sequences from $P$. denitrificans and Roseobacter denitrificans, to the data set. The results of this experiment are shown in Table 2, which shows the overall percentages of similarity obtained after pairwise sequence alignment, as well as the corrected distance values calculated for the alignable 1,346 positions of the entire set. The levels of sequence similarity between the Rhodobacter test strains ranged from 91.6 to $100 \%$. It is important to note that the freshwater species Rhodobacter capsulatus, Rhodobacter sphaeroides, and Rhodobacter veldkampii are more similar to each other (level of similarity, $>94.8 \%$ ) than to the marine species Rhodobacter adriaticus, Rhodobacter euryhalinus, and Rhodobacter sulfidophilus. In contrast, the marine species are more similar to each other (level of similarity, $>93.9 \%$ ) than to the freshwater species. The levels of similarity between the freshwater and marine species range from 91.6 to $94.4 \%$. As expected from the previously published molecular information $(4,29)$, Rhodopseudomonas blastica exhibits relatively high levels of sequence similarity (ca. 95\%) to the freshwater Rhodobacter species.

A distance matrix tree was reconstructed by the neighborjoining method by using the corrected values for the 13 test strains and the 2 reference organisms (Fig. 1). The intrageneric structure of the genus Rhodobacter is clear on the phylogenetic tree, as the freshwater and marine species of this genus are separated into two major clusters. A bootstrap analysis confirmed the monophyly of the cluster that in- cluded the marine Rhodobacter species in $99.8 \%$ of the 1,000 trees generated. Newly isolated Rhodobacter sp. strains MB260 and MB-G2 were included in the cluster containing the marine species. The tree topography suggests that the former strain is related to Rhodobacter sulfidophilus, while the latter may be a member of a new marine species. The cluster containing the freshwater Rhodobacter species also included Rhodopseudomonas blastica and was linked more closely to the chemotroph $P$. denitrificans than to the marine Rhodobacter group. These results not only confirm the previous findings concerning the genealogical relationships among Rhodobacter species, Rhodopseudomonas blastica, and $P$. denitrificans, but also demonstrate that there is still phylogenetic diversity within the genus Rhodobacter.

The 16S rDNA sequences of the six established species and one unknown species (strain MB-G2) belonging to the genus Rhodobacter were also compared with the sequences of nine reference species of alpha group phototrophs in addition to the sequences of $P$. denitrificans and Roseobacter denitrificans, and another phylogenetic tree was constructed by using the evolutionary distance values calculated for the 1,209 positions that could be aligned (Fig. 2). This tree shows that the species of the genus Rhodobacter, together with $P$. denitrificans and Roseobacter denitrificans, form a major cluster which is relatively distant from the lineages containing other members of the alpha group of phototrophic bacteria. Within the Rhodobacter branch, this tree has almost the same topography as the tree shown in Fig. 1. In particular, the Rhodobacter cluster consists of two separate lineages; one lineage includes the freshwater Rhodobacter species linked to $P$. denitrificans and Roseobacter denitrificans as the nearest neighbors, and the other lineage includes the marine Rhodobacter species.

The results of genomic DNA-DNA hybridization studies were consistent with those of $16 \mathrm{~S}$ rDNA sequence comparisons (Table 3). The freshwater Rhodobacter species and Rhodopseudomonas blastica exhibited DNA-DNA homology levels of more than $15 \%$ in comparisons with the type strain of Rhodobacter capsulatus. On the other hand, the homology levels were somewhat lower ( 9 to $14 \%$ ) between the marine species and the type species, Rhodobacter capsulatus. The reverse was true when DNAs were paired with labeled DNA from the marine species Rhodobacter sulfidophilus. The DNA-DNA homology values obtained indicate that the levels of genetic relatedness between the freshwater and marine Rhodobacter species are relatively low for members of a genus. DNA-DNA hybridization studies also provided some interesting information about the taxonomic position of new isolate MB260. This strain has been shown to be related to Rhodobacter sulfidophilus on the basis of 16S rDNA sequence data, as noted above, but exhibited $53 \%$ DNA homology to the type strain of Rhodobacter sulfidophilus, suggesting that the two taxa differ at the species level. Our DNA base composition data for some species were different from data obtained previously. In particular, this was true for Rhodobacter sulfidophilus, for which we found $\mathrm{G}+\mathrm{C}$ contents of 66.3 to $66.6 \mathrm{~mol} \%$ (as determined by HPLC), values that were much lower than the previously reported values $(3,14)$.

While there has been no general agreement regarding the phylogenetic definition of a genus (41), Johnson (27) has stated that the minimum DNA-DNA homology level for members of a genus should be $20 \%$. Plotting the 16S rDNA sequence similarity values against the DNA-DNA homology values for each pair of test organisms revealed that $20 \%$ DNA-DNA homology corresponded to a level of 16S rRNA 


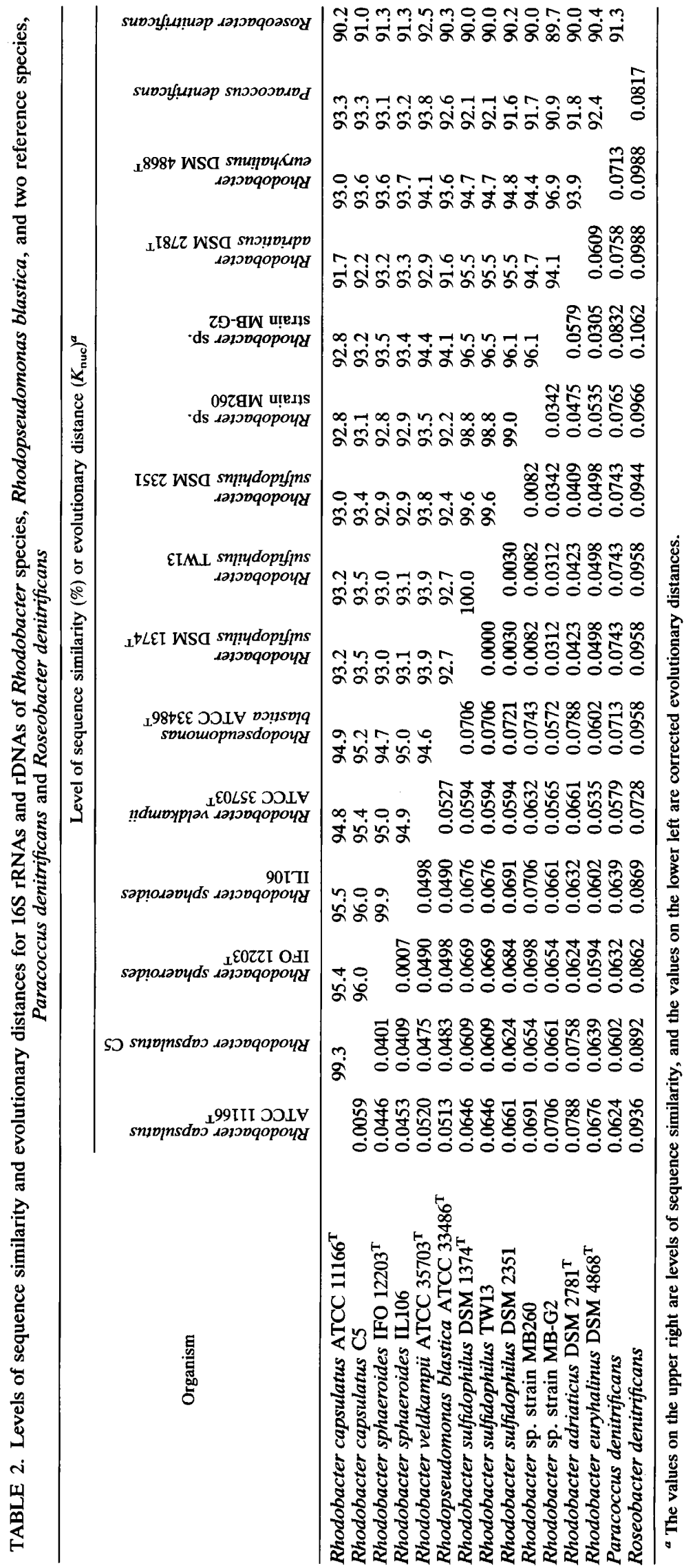




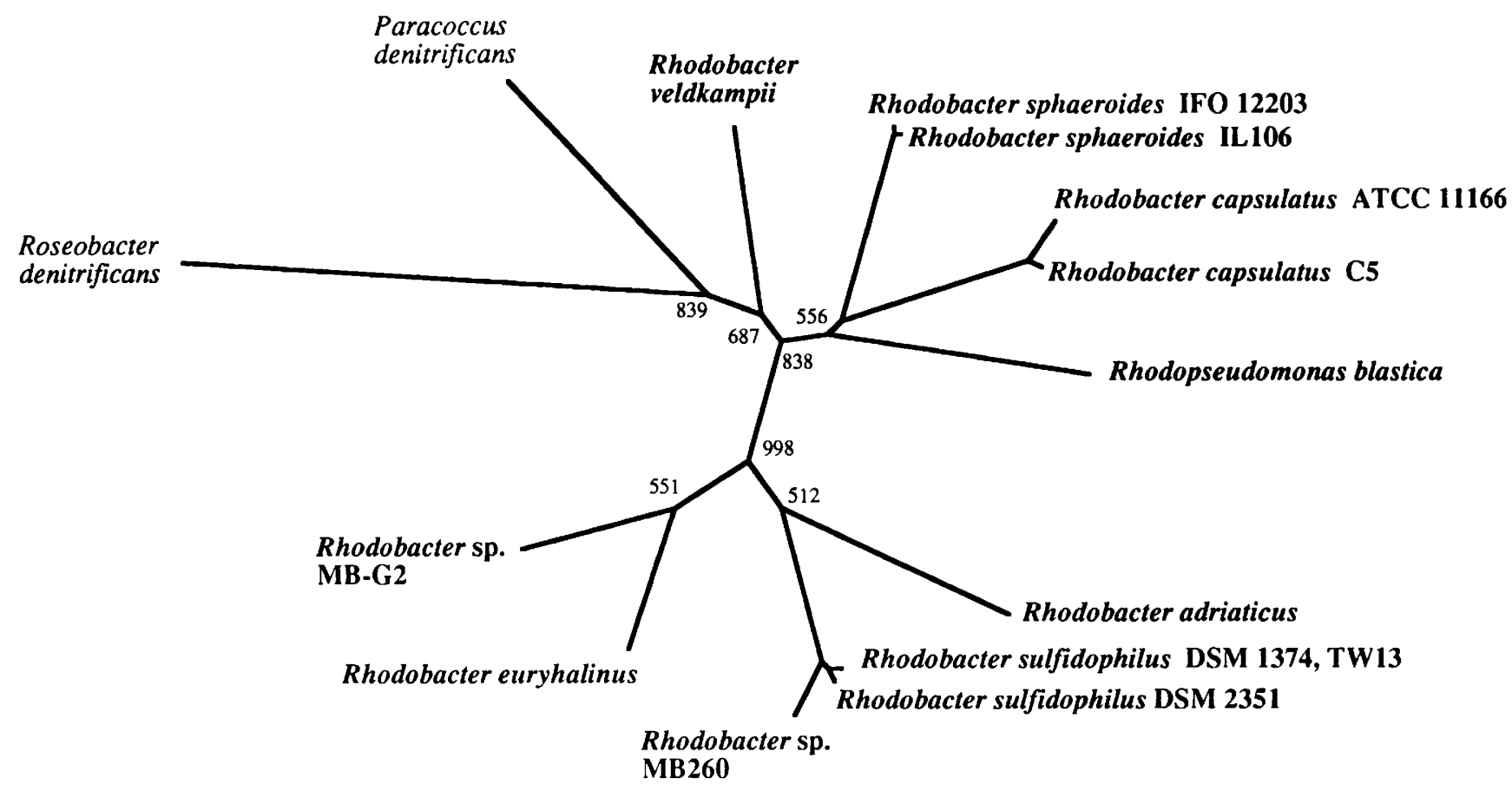

FIG. 1. Unrooted distance matrix tree showing phylogenetic relationships among the test strains of Rhodobacter species and $R$ hodopseudomonas blastica, as well as $P$. denitrificans and Roseobacter denitrificans. The bacteria examined for $16 \mathrm{~S}$ rDNA sequences in this study are indicated by boldface type. Bootstrap confidence values are given at branching points of interest. Bar $=0.01 K_{\text {nuc }}$.

sequence similarity of ca. $96 \%$ (Fig. 3). If these criteria are used to define a generic boundary, the Rhodobacter species can be separated into two or more genera. In addition, the freshwater and marine Rhodobacter species may be related phylogenetically above the genus level.

The current genus Rhodobacter was proposed on the basis of phenotypic, chemotaxonomic, and molecular data when the purple nonsulfur bacteria were reclassified (25). This genus is more coordinated than the other genera of phototrophic bacteria belonging to the alpha subclass of the Proteobacteria. Nevertheless, as reported in this paper, our detailed phylogenetic analyses performed with information on 16S rRNA gene sequences and levels of genomic DNA homology have revealed that there is phylogenetic diversity among members of the genus Rhodobacter and that there are two separate lineages, one of which includes the freshwater species and one of which includes the marine species. The 16S rRNA-based tree topography showing the marine species cluster as a monophyletic group is supported by a high level of bootstrap confidence. The molecular data also suggest that the freshwater Rhodobacter species are more closely related to the nonphototrophic bacterium $P$. denitrificans than to the marine species. From a phylogenetic standpoint, therefore, it is logical to conclude that all of the marine species Rhodobacter adriaticus, Rhodobacter euryhalinus, and Rhodobacter sulfidophilus should be removed from the genus Rhodobacter and placed in a new genus. We propose that all marine Rhodobacter species should be transferred to the genus Rhodovulum gen. nov.; Rhodovulum sulfidophilum comb. nov. is the type species of this genus. Although in the new genus Rhodovulum there are still variations in levels of interspecific 16S rRNA and genomic DNA homology within a relatively broad range, it is appro- priate, at present, to place the three marine species in a single genus on the basis of their phenotypic homogeneity, as described below.

In the taxonomy of Rhodobacter species, as well as in the taxonomy of many other bacterial taxa, a salt requirement for growth and natural habitats (freshwater or marine origin) are important traits. Our proposal for creation of the new genus Rhodovulum clarifies the taxonomic problem concerning the heterogeneity of the Rhodobacter species in these respects. Following the transfer of the marine species to the genus Rhodovulum, the genus Rhodobacter should include only freshwater species. There are some other phenotypic characteristics that are useful for differentiating the genus Rhodovulum from the genus Rhodobacter sensu stricto. Sulfide tolerance is considerably higher in the marine species than in the freshwater species, and the final oxidation product of sulfide is sulfate in the former species and sulfur in the latter species $(12,14,23,31,35)$; Rhodobacter veldkampii is an exception to these general statements (12). In tests for photoassimilation of organic substrates, utilization of the one-carbon compound formate has been found mainly in the marine species $(14,31,35)$; this characteristic has also been found in new isolates MB260 and MB-G2 (21). Polar lipid profiles may also be useful as diagnostic characteristics. The marine species contain sulfolipids (probably sulfoquinovosyldiglyceride) but not phosphatidylcholine, while the freshwater species are heterogeneous for these characteristics (24). Characteristic differences in 16S rRNA nucleotide signatures are found for the genera Rhodovulum and Rhodobacter sensu stricto, indicating the usefulness of molecular information, as well as phenotypic traits, for identification and classification of strains of the two genera. 


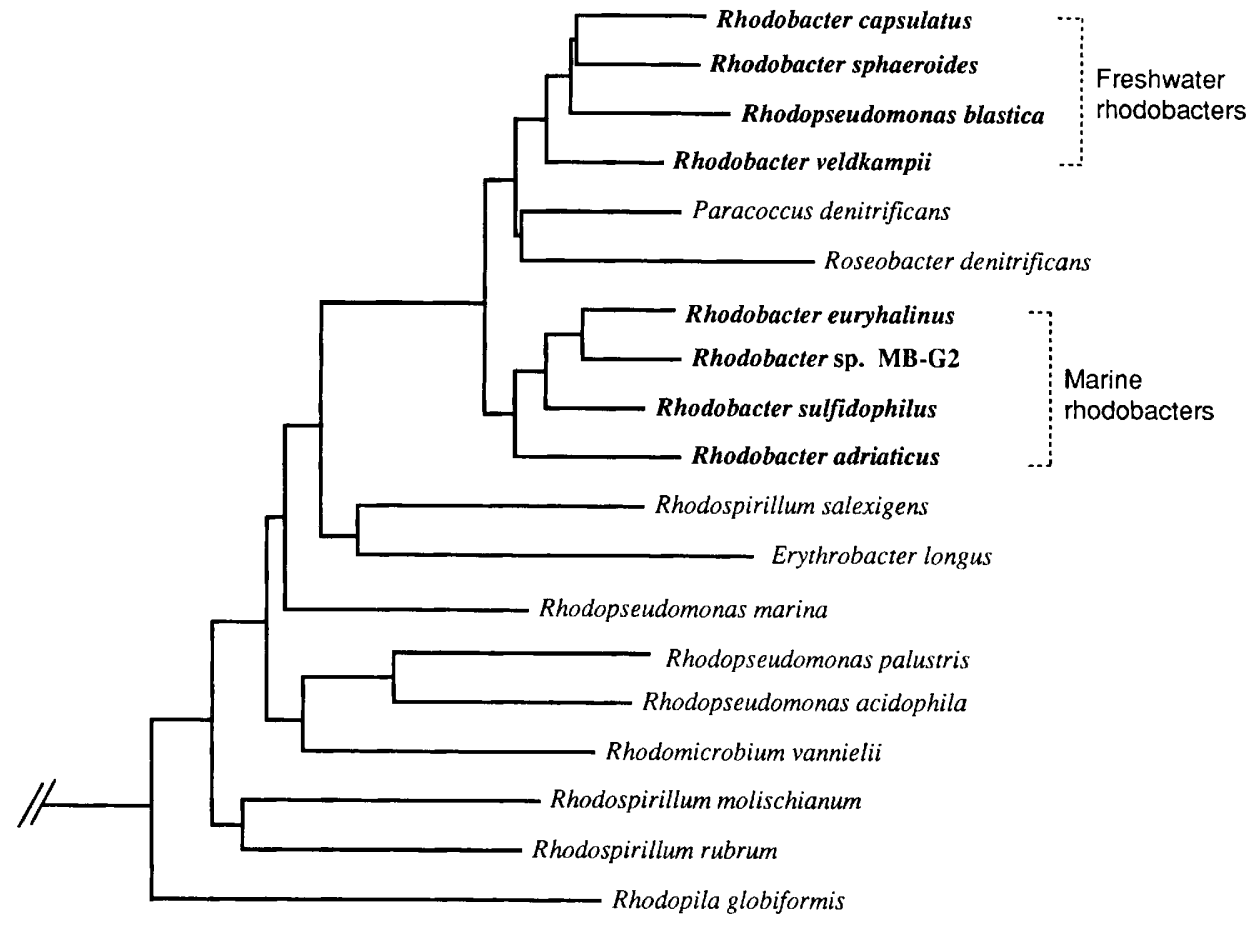

FIG. 2. Unrooted distance matrix tree showing phylogenetic relationships of Rhodobacter species (represented by their type strains [except strain MB-G2]) and other phototrophic and nonphototrophic bacteria belonging to the alpha subclass of the Proteobacteria. The Escherichia coli sequence was used as an outlier sequence to root the tree. The lengths of the horizontal lines are proportional to the evolutionary distances, while the lengths of the vertical lines are meaningless. The species examined for 16S rDNA sequences in this study are indicated by boldface type. Bar $=0.02 K_{\text {nuc }}$.

The differential characteristics of the two genera are summarized in Table 4.

Because of the transfer of the marine species to the genus Rhodovulum, the description of the genus Rhodobacter must be emended, and Rhodopseudomonas blastica must be reclassified as a member of the latter genus. However, some taxonomic problems concerning the circumscription of the genus Rhodobacter remain. Compared with the species of the genus Rhodovulum, the members of the genus Rhodo- bacter sensu stricto seem to exhibit more phenotypic diversity in key characteristics (for example, in sulfur metabolism and polar lipid profiles) (Table 4). Also, the proposal to incorporate Rhodopseudomonas blastica into the genus Rhodobacter (29) complicates the problems because of the resulting rejection of some important phenotypic characteristics (i.e., mode of cell division, photosynthetic membrane systems, and sulfide utilization) as generic criteria. We prefer to transfer Rhodopseudomonas blastica and Rhodo-

TABLE 3. Levels of genomic DNA relatedness for test strains of Rhodobacter species and Rhodopseudomonas blastica

\begin{tabular}{|c|c|c|c|}
\hline \multirow[b]{2}{*}{ Organism } & \multirow{2}{*}{$\underset{(\mathrm{mol} \%)}{\mathrm{G}+\mathrm{C} \text { content }}$} & \multicolumn{2}{|c|}{$\%$ Homology with labeled DNA from: } \\
\hline & & 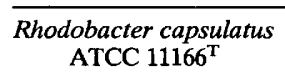 & $\begin{array}{c}\text { Rhodobacter sulfidophilus } \\
\text { DSM } 1374^{\mathrm{T}}\end{array}$ \\
\hline \multicolumn{4}{|l|}{ Freshwater strains } \\
\hline Rhodobacter capsulatus ATCC $11166^{\mathrm{T}}$ & 65.9 & 100 & 14 \\
\hline Rhodobacter capsulatus C5 & 66.3 & 60 & 14 \\
\hline Rhodobacter sphaeroides IFO $12203^{\mathrm{T}}$ & 69.0 & 20 & 13 \\
\hline Rhodobacter sphaeroides IL106 & 69.2 & 22 & 12 \\
\hline Rhodobacter veldkampii ATCC $35703^{\mathrm{T}}$ & 66.5 & 15 & 10 \\
\hline Rhodopseudomonas blastica ATCC $33486^{\mathrm{T}}$ & 65.6 & 16 & 8 \\
\hline \multicolumn{4}{|l|}{ Marine strains } \\
\hline Rhodobacter adriaticus DSM $2781^{\mathrm{T}}$ & 65.0 & 9 & 16 \\
\hline Rhodobacter euryhalinus DSM $4868^{\mathrm{T}}$ & 65.5 & 10 & 14 \\
\hline Rhodobacter sulfidophilus DSM $1374^{\mathrm{T}}$ & 66.3 & 14 & 100 \\
\hline Rhodobacter sulfidophilus DSM 2351 & 66.6 & 13 & 73 \\
\hline Rhodobacter sulfidophilus TW13 & 66.4 & 11 & 95 \\
\hline Rhodobacter sp. strain MB260 & 66.6 & 11 & 53 \\
\hline Rhodobacter sp. strain MB-G2 & 67.5 & 11 & 20 \\
\hline
\end{tabular}




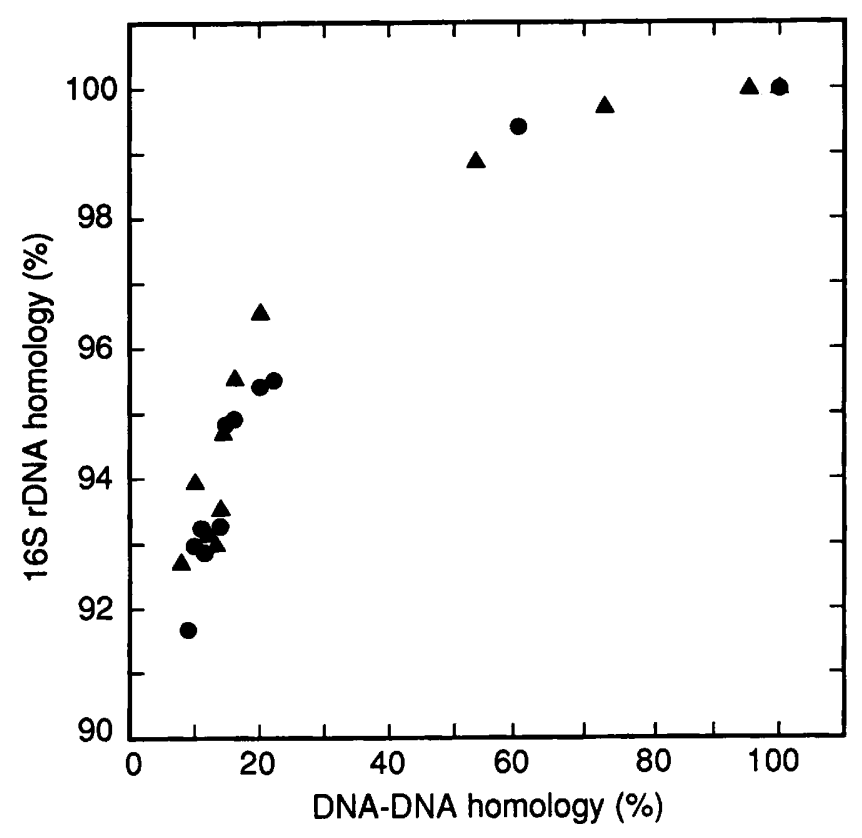

FIG. 3. Relationship between level of 16S rDNA sequence homology and level of genomic DNA homology for pairs of Rhodobacter strains. Symbols: $\bullet$, homology values determined with Rhodobacter capsulatus ATCC $11166^{\mathrm{T}}$; $\mathbf{\Delta}$, homology values determined with Rhodobacter sulfidophilus DSM $1374^{\mathrm{T}}$.

bacter veldkampii for practical reasons to separate new genera, but will not present nomenclatural and taxonomic proposals to do this until more information and more strains related to these taxa become available.

Description of Rhodovulum gen. nov. Rhodovulum (Rho.do'vu.lum. Gr. n. rhodos, rose; L. dim. n. ovulum, small egg; M. L. neut.n. Rhodovulum, small red egg). The characteristics described below are based on information obtained from Imhoff et al. (23-25) and this study. Cells are ovoid to rod shaped, 0.5 to $0.9 \mu \mathrm{m}$ wide, and 0.9 to $2.0 \mu \mathrm{m}$ long. Motile by means of a single polar flagellum or nonmotile. Cells divide by binary fission. Gram negative. Facultatively anaerobic phototrophs which grow under anaerobic conditions in the light or under aerobic conditions in the dark. Phototrophically grown cells form vesicular intracytoplasmic membranes together with bacteriochlorophyll $a$ (esterified with phytol) and carotenoids of the spheroidene series. The color of phototrophic cultures is yellow-green to yellow-brown, while aerobic cultures are pink to red. Mesophilic and halophilic. Sodium chloride at a concentration of 0.5 to $7.5 \%$ is required for optimal growth. Photoorganotrophy with various organic compounds is the preferred mode of growth. Good carbon sources are pyruvate, lactate, lower fatty acids, intermediates of the citric acid cycle, and some sugars. Growth on formate also occurs. Photoautotrophic or photoheterotrophic growth occurs in the presence of sulfide or thiosulfate as the electron donor. Growth occurs in the presence of high sulfide concentrations ( $2 \mathrm{mM}$ or more). The final oxidation product of sulfide is sulfate. Ubiquinone 10 is the major quinone. The major fatty acid is $C_{18: 1}$. Membrane lipids contain sulfolipids but not phosphatidylcholine. The $\mathrm{G}+\mathrm{C}$ content of the genomic DNA ranges from 62 to 69 mol\%. The phylogenetic position is the alpha subclass $(\alpha-3)$ of the Proteobacteria. Natural habitats are marine and hypersaline environments. The type species is Rhodovulum sulfidophilum.

Description of Rhodovulum sulfidophilum comb. nov. Rhodovulum sulfidophilum (Rhodobacter sulfidophilus (Hansen and Veldkamp 1973) Imhoff, Trüper, and Pfennig 1984) (sul.fi.do'phi.lum. N. L. n. sulfidum, sulfide; Gr. adj. philus, loving; M. L. adj. sulfidophilum, sulfide loving). The characteristics are the same as the characteristics described above for the genus. Additional properties have been described previously $(14,23-25)$. The $G+C$ content of the

TABLE 4. Differential phenotypic characteristics and 16S rRNA nucleotide signatures of the genera Rhodovulum gen. nov. and Rhodobacter sensu stricto ${ }^{a}$

\begin{tabular}{|c|c|c|}
\hline Characteristic & Rhodovulum & Rhodobacter \\
\hline Salt required for optimal growth & $t^{b}$ & - \\
\hline Final oxidation product of sulfide & $\mathrm{SO}_{4}{ }^{2-}$ & $\mathrm{S}^{0} / \mathrm{SO}_{4}^{2-}$ \\
\hline Sulfide tolerance $(>2 \mathrm{mM})$ & + & $-1+$ \\
\hline \multicolumn{3}{|l|}{ Utilization of: } \\
\hline Thiosulfate & + & $-1+$ \\
\hline Formate & + & $-1+$ \\
\hline \multicolumn{3}{|l|}{ Polar lipid composition: } \\
\hline Sulfolipid & + & $-1+$ \\
\hline Phosphatidylcholine & - & $+1-$ \\
\hline $\begin{array}{l}\mathrm{G}+\mathrm{C} \text { content of genomic DNA } \\
(\mathrm{mol} \%)\end{array}$ & $62-69$ & $64-70$ \\
\hline Natural habitat & Hypersaline and marine environments & Freshwater and terrestrial environments \\
\hline \multicolumn{3}{|l|}{ 16S rRNA signature(s) at position(s): } \\
\hline $241-285$ & $\mathrm{~A}-\mathrm{U} / \mathrm{U}-\mathrm{A}$ & $\mathrm{G}-\mathrm{C}$ \\
\hline 278 & $\mathrm{~T}$ & $\mathrm{G}$ \\
\hline 360 & A & G \\
\hline 579 & $\mathrm{G}$ & A \\
\hline 653 & $\mathrm{~A} / \mathrm{G}$ & $\mathbf{T}$ \\
\hline $1310-1327$ & U-G & $\mathrm{G}-\mathrm{C}$ \\
\hline $1311-1326$ & $\mathrm{~T}-\mathrm{A} / \mathrm{C}-\mathrm{G}$ & $\mathrm{G}-\mathrm{C}$ \\
\hline $1312-1325$ & $\mathrm{C}-\mathrm{G}$ & $\mathrm{G}-\mathrm{C}$ \\
\hline $1426-1474$ & $\mathbf{T}-\mathbf{A}$ & $\mathrm{C}-\mathrm{G}$ \\
\hline
\end{tabular}

a Data from references $12,14,23,24,31$, and 35 and this study.

$b+$, positive; - , negative; $-1+$ and $+/-$, variable reaction (the first sign indicates the most frequent result). 
DNA ranges from 66.3 to $66.6 \mathrm{~mol} \%$ (as determined by HPLC). The type strain is DSM 1374 (= ATCC $35886=$ Hansen W4).

Description of Rhodovulum adriaticum comb. nov. Rhodovulum adriaticum (Rhodobacter adriaticus (Neutzling, Imhoff, and Trüper 1984) Imhoff, Trüper, and Pfennig 1984) (a.dri.a'ti.cum. M.L. masc. adj. adriaticum pertaining to the Adriatic Sea). The characteristics are the same as the characteristics described above for the genus. Additional properties have been described previously $(23-25,35)$. The $\mathrm{G}+\mathrm{C}$ content of the DNA ranges from 64.9 to $66.7 \mathrm{~mol} \%$ (as determined by the thermal denaturation method). The type strain is DSM 2781 (= ATCC 35885 = Imhoff 6II).

Description of Rhodovulum euryhalinum comb. nov. Rhodovulum euryhalinum (Rhodobacter euryhalinus Kompantseva 1985) (eu.ry.ha'li.num. Gr. adj. eurys, wide; Gr. n. halts, salt; M. L. masc. adj. euryhalinum, wide range salinity living). The characteristics are the same as the characteristics described above for the genus. Additional properties have been described previously (31). The $\mathrm{G}+\mathrm{C}$ content of the DNA was reported to range from 62.1 to $68.6 \mathrm{~mol} \%$ in the original description (31), but this broad range of base ratios may have resulted from heterogeneity of the test strains at the species level. The base composition of the type strain is $65.5 \mathrm{~mol} \% \mathrm{G}+\mathrm{C}$ (as determined by HPLC) or 66.3 $\mathrm{mol} \% \mathrm{G}+\mathrm{C}$ (as determined by the thermal denaturation method). The type strain is DSM 4868 (= Kompantseva KA-65).

\section{REFERENCES}

1. Ambler, R. P., R. G. Bartsch, M. Daniel, J. Hermoso, M. D. Kamen, and T. E. Meyer. 1979. Cytochrome $c_{2}$ sequence variation among the recognized species of purple nonsulphur photosynthetic bacteria. Nature (London) 278:659-660.

2. Brosius, J., J. L. Palmer, J. P. Kennedy, and H. F. Noller. 1978. Complete nucleotide sequence of a 16S ribosomal RNA gene from Escherichia coli. Proc. Natl. Acad. Sci. USA 75:48014805 .

3. DeBont, J. A. M., A. Scholten, and T. A. Hansen. 1981. DNA-DNA hybridization of Rhodopseudomonas capsulata, Rhodopseudomonas sphaeroides, and Rhodopseudomonas sulfidophila strains. Arch. Microbiol. 128:271-274.

4. De Ley, J. 1992. The proteobacteria: ribosomal RNA cistron similarities and bacterial taxonomy, p. 2111-2140. In A. Balows, H. G. Trüper, M. Dworkin, W. Harder, and K. H. Schleifer (ed.), The prokaryotes, 2nd ed. Springer-Verlag, Berlin.

5. Dickerson, R. E. 1980. Evolution and gene transfer in purple photosynthetic bacteria. Nature (London) 283:210-212.

6. Drynden, S. C., and S. Kaplan. 1990. Localization and structural analysis of the ribosomal RNA operons of Rhodobacter sphaeroides. Nucleic Acids Res. 18:7267-7277.

7. Eckersley, K., and C. S. Dow. 1980. Rhodopseudomonas blastica sp. nov.: a member of the Rhodospirillaceae. J. Gen. Microbiol. 119:465-473.

8. Embley, T. M. 1991. The linear PCR reaction: a simple and robust method for sequencing amplified rRNA genes. Lett. Appl. Microbiol. 13:171-174.

9. Ezaki, T., S. Dejsirilert, H. Yamamoto, N. Takeuchi, S. Liu, and E. Yabuuchi. 1988. Simple and rapid genetic identification of Legionella species with photobiotin-labeled DNA. J. Gen. Appl. Microbiol. 34:191-199.

10. Felsenstein, J. 1985. Confidence limits on phylogenies: an approach using the bootstrap. Evolution 39:783-791.

11. Gibson, J., E. Stackebrandt, L. B. Zablen, R. Gupta, and C. R. Woese. 1979. A phylogenetic analysis of the purple photosynthetic bacteria. Curr. Microbiol. 3:59-64.

12. Hansen, T. A., and J. F. Imhoff. 1985. Rhodobacter veldkampii a new species of phototrophic purple nonsulfur bacteria. Int. J.
Syst. Bacteriol. 35:115-116.

13. Hansen, T. A., and H. van Gemerden. 1972. Sulfide utilization by purple nonsulfur bacteria. Arch. Mikrobiol. 86:49-56.

14. Hansen, T. A., and H. Veldkamp. 1973, Rhodopseudomonas sulfidophila, nov. spec., a new species of the purple nonsulfur bacteria. Arch. Mikrobiol. 92:45-58.

15. Higgins, D. G., A. J. Bleasby, and R. Fuchs. 1992. CLUSTAL V: improved software for multiple sequence alignment. Comput. Appl. Biosci. 8:189-191.

16. Hiraishi, A. 1992. Direct automated sequencing of 16S rDNA amplified by polymerase chain reaction from bacterial cultures without DNA purification. Lett. Appl. Microbiol. 15:210-213.

17. Hiraishi, A. Phylogenetic affiliations of Rhodoferax fermentans and related species of phototrophic bacteria as determined by automated 16S rDNA sequencing. Curr. Microbiol., in press.

18. Hiraishi, A., and Y. Hoshino. 1984. Distribution of rhodoquinone in Rhodospirillaceae and its taxonomic implications. J. Gen. Appl. Microbiol. 30:435-448.

19. Hiraishi, A., Y. Hoshino, and H. Kitamura. 1984. Isoprenoid quinone composition in the classification of Rhodospirillaceae. J. Gen. Appl. Microbiol. 30:197-210.

20. Hiraishi, A., Y. Hoshino, and T. Satoh. 1991. Rhodoferax fermentans gen. nov., sp. nov., a phototrophic purple nonsulfur bacterium previously referred to as the "Rhodocyclus gelatinosus-like"' group. Arch. Microbiol. 155:330-336.

21. Hiraishi, A., and Y. Ueda. Unpublished data.

22. Imhoff, J. F. 1984. Quinones of phototrophic purple bacteria. FEMS Microbiol. Lett. 25:85-89.

23. Imhoff, J. F. 1989. Genus Rhodobacter Imhoff, Trüper and Pfennig $1984,342^{\text {VP }}$, p. 1668-1672. In J. T. Staley, M. P. Bryant, N. Pfennig, and J. G. Holt (ed.), Bergey's manual of systematic bacteriology, vol. 3. The Williams \& Wilkins Co., Baltimore.

24. Imhoff, J. F. 1991. Polar lipids and fatty acids in the genus Rhodobacter. Syst. Appl. Microbiol. 14:228-234.

25. Imhoff, J. F., H. G. Trüper, and N. Pfennig. 1984. Rearrangement of the species and genera of the phototrophic "purple nonsulfur bacteria." Int. J. Syst. Bacteriol. 34:340-343.

26. Ivanova, T. L., T. P. Turova, and A. S. Antonov. 1988. DNADNA hybridization studies on some purple nonsulfur bacteria. Syst. Appl. Microbiol. 10:259-263.

27. Johnson, J. L. 1984. Nucleic acids in bacterial classification, p 8-11. In N. R. Krieg and J. G. Holt (ed.), Bergey's manual of systematic bacteriology, vol. 1. The Williams \& Wilkins Co., Baltimore.

28. Kato, S., T. Urakami, and K. Komagata. 1985. Quinone systems and cellular fatty acid composition in species of Rhodospirillaceae genera. J. Gen. Appl. Microbiol. 31:381-398.

29. Kawasaki, H., Y. Hoshino, A. Hirata, and K. Yamasato. Is intracytoplasmic membrane structure a generic criterion? It does not coincide with phylogenetic interrelationships among phototrophic purple nonsulfur bacteria. Arch. Microbiol., in press.

30. Kimura, M. 1980. A simple method for estimating evolutionary rates of base substitution through comparative studies of nucleotide sequences. J. Mol. Evol. 16:111-120.

31. Kompantseva, E. I. 1985. New halophilic purple bacteria, Rhodobacter euryhalinus sp. nov. Mikrobiogiya 54:974-982. (In Russian.)

32. Ludwig, W., G. Mittenhuber, and C. G. Friedrich. 1993. Transfer of Thiosphaera pantotropha to Paracoccus denitrificans. Int. J. Syst. Bacteriol. 43:363-367.

33. Marmur, J. 1961. A procedure for the isolation of deoxyribonucleic acid from micro-organisms. J. Mol. Biol. 3:208-218.

34. Murray, V. 1989. Improved double stranded DNA sequencing using the linear polymerase chain reaction. Nucleic Acids Res. 17:8889.

35. Neutzling, O., J. F. Imhoff, and H. G. Trüper. 1984. Rhodopseudomonas adriatica sp. nov., a new species of the Rhodospirillaceae, dependent on reduced sulfur compounds. Arch. Microbiol. 137:256-261.

36. Pfennig, N., and H. G. Trüper. 1971. Type and neotype strains of the species of phototrophic bacteria maintained in pure culture. Int. J. Syst. Bacteriol. 21:19-24. 
37. Saitou, N., and M. Nei. 1987. The neighbor-joining method: a new method for reconstructing phylogenetic trees. Mol. Biol. Evol. 4:406-425.

38. Satoh, T., Y. Hoshino, and H. Kitamura. 1976. Rhodopseudomonas sphaeroides forma sp. denitrificans, a denitrifying strain as a subspecies of Rhodopseudomonas sphaeroides. Arch. Microbiol. 108:265-269.

39. Stackebrandt, E., R. G. E. Murray, and H. G. Trüper. 1988. Proteobacteria classis nov., a name for the phylogenetic taxon that includes the "purple bacteria and their relatives." Int. J. Syst. Bacteriol. 38:321-325.

40. Tayeh, M. A., and M. T. Madigan. 1992. Comparative immunological analyses of the citric acid cycle enzyme malate dehydrogenase from phototrophic purple bacteria. Syst. Appl. Microbiol. 15:331-335.

41. Wayne, L. G., D. J. Brenner, R. R. Colwell, P. A. D. Grimont, O. Kandler, M. I. Krichevsky, L. H. Moore, W. E. C. Moore, R. G. E. Murray, E. Stackebrandt, M. P. Starr, and H. G. Trüper. 1987. Report of the Ad Hoc Committee on Reconciliation of Approaches to Bacterial Systematics. Int. J. Syst.
Bacteriol. 37:463-464.

42. Weckesser, J., and H. Mayer. 1987. Lipopolysaccharide aus phototrophen Bakterien. Forum Mikrobiol, 10:242-248.

43. Weckesser, J., and H. Mayer. 1988. Different lipid A types in lipopolysaccharides of phototrophic and related non-phototrophic bacteria. FEMS Microbiol. Rev. 54:143-154.

44. Weisburg, W. G., S. M. Barns, D. A. Pelletier, and D. J. Lane. 1991. 16S ribosomal DNA amplification for phylogenetic study. J. Bacteriol. 173:697-703.

45. Woese, C. R. 1987. Bacterial evolution. Microbiol. Rev. 51:221271.

46. Woese, C. R., J. Gibson, and G. E. Fox. 1980. Do genealogical patterns in purple photosynthetic bacteria reflect interspecific gene transfer? Nature (London) 283:212-214.

47. Woese, C. R., E. Stackebrandt, W. G. Weisburg, B. J. Paster, M. T. Madigan, V. J. Fowler, C. M. Hahn, P. Blanz, R. Gupta, K. H. Nealson, and G. E. Fox. 1984. The phylogeny of purple bacteria: the alpha subdivision. Syst. Appl. Microbiol. 5:315326. 